\title{
Global system for mobile communication based domestic electrical load control using arduino uno
}

\author{
L. Velusamy ${ }^{1}$, S. Salimin' ${ }^{2}$, S. N. M. Rozi ${ }^{3}$, M. N. Abdullah ${ }^{4}$, N. H. Radzi ${ }^{5}$, \\ S. A. Jumaat ${ }^{6}$, R. Hamdan ${ }^{7}$ \\ ${ }^{1,3}$ Faculty of Electrical and Electronic Engineering, Universiti Tun Hussein Onn Malaysia (UTHM), Malaysia \\ ${ }^{2,4,5,6,7}$ Green and Sustainable Energy Focus Group (GSEnergy), Faculty of Electrical and Electronic Engineering, \\ Universiti Tun Hussein Onn Malaysia (UTHM), Malaysia
}

\begin{tabular}{|c|c|}
\hline Article Info & ABSTRACT \\
\hline Article history: & \multirow{10}{*}{$\begin{array}{l}\text { This paper presents a wireless operation to switch on and off the load such as } \\
\text { light, fan and power socket by sending messages via smartphone. The } \\
\text { proposed project is focused on usage of the global system for mobile } \\
\text { communication (GSM) protocol, which enables the user to control loads away } \\
\text { from targeted area using the frequency bandwidths. The concept of serial } \\
\text { communication and Uno microcontroller-commands are being applied } \\
\text { towards development of the GSM based domestic electrical load control using } \\
\text { Arduino UNO system. Besides that, the existing electrical switches that } \\
\text { control the load manually is not being removed and this gives a safer control } \\
\text { over the switches with low voltage usage technique. This system is designed } \\
\text { to control electrical devices throughout the house with easy installation } \\
\text { process, ease of use and cost effective design and implementation. } \\
\text { Additionally, the system has several possibility to help satisfy the needs of the } \\
\text { elderly and the handicapped at houses. Prototype of GSM based domestic } \\
\text { electrical load control using Arduino UNO was implemented and successfully } \\
\text { tested with maximum of five loads such as light, fan and power sockets. }\end{array}$} \\
\hline Received Jan 5, 2019 & \\
\hline Revised Mar 20, 2019 & \\
\hline Accepted May 10, 2019 & \\
\hline & \\
\hline Keywords: & \\
\hline Domestic load & \\
\hline Mobile technology & \\
\hline Wireless & \\
\hline & \\
\hline
\end{tabular}

Copyright $(0) 2019$ Institute of Advanced Engineering and Science. All rights reserved.

\section{Corresponding Author:}

Suriana binti Salimin,

Green and Sustainable Energy Focus Group (GSEnergy),

Faculty of Electrical and Electronic Engineering,

Universiti Tun Hussein Onn Malaysia,

86400 Parit Raja, Batu Pahat, Johor, Malaysia.

Email: suriana@uthm.edu.my

\section{INTRODUCTION}

The home automated system is an idea or concept where the system has the ability to conduct task to initiate or control electrical appliances at home. Since technology rapidly developing, a lot of electrical goods in the market are found. Therefore, needed more attention to controlling such as by using devices. So that, the concept of smart home automation in practice is to control the electrical appliance [1]. The popularity of smart home automation began to increase due to differences in technology started to arise. Previously, people switch off or on the load only done by manually. In another way, the system will provide assistance for disabled or elderly individuals when they want to switch on or off the load [2, 3]. After introducing the remote control people feel very easy to control home appliances by avoiding physically present. In addition, smart home automation became a more affordable choice for inhabitants and therefore a viable or available technology for consumers. With the uprising of the prestige of smart home, home networking, domestic technologies, and other gadgets began to emerge on store shelves. Today's smart home automation is more emphasize about smart living, living greener and security. The smart home is sustainable and it ensures that home is not utilizing 
unnecessary energy. In this case, the utility bill will be reduced due to switching offload immediately if not in use. The current trend in smart home automation includes automated lights, remotely mobile control, remote video surveillance and receiving notifications of mobile, email and text [4-9]. For the future of home automation, the prediction or prophecy that the smart home's future will be added a security system that can prevent any intrusion or robbery by alerting us with alarm or send any signal to us through smartphone related application. It will be helpful for decreasing criminal activities and give assurance to people life. Finally, this home automation system that emerges in this way is providing more freedom and a higher quality of life to consumers.

\section{LITERATURE REVIEW}

A number or researches has been done to control parameters remotely. Aguado $\mathrm{M}$ et.al stated that by modeling the functional behavior and the communication part in the same framework, they are able to detect failures in the communication link that can affect the railway system performance [10]. Another study by Peng Wang et.al proposed a system that can provide real-time online observation of the controlling and monitoring of security, remote temperature as well as fireproof home appliances based on wireless general package radio service (GPRS) and Internet [11]. Besides, many have also proved the effectiveness of automatic controlling system using Bluetooth, power line carrier communication (PLCC), dual tone multi frequency (DTMF), GPRS and GSM [12-19].

Furthermore, there are a couple of activities accomplished territorially by a method for other undergraduate and specialist in Malaysia with respect to on the voice-related research [20, 21]. Professor Mahesh N. Jivani, from the branch of Electronics of Saurashtra school, had been produced android cell phone applications related residential robotization to enhance the estimation of lives via computerizing various electrical hardware [22]. He transformed into utilized application creator as a cutting edge obvious programming stage for creating versatile bundles for Android-basically based advanced mobile phones. The Android wireless Platform transforms into additional and more well known among programming program designers, on account of its capable abilities and open engineering. It's far a remarkable stage for the genuine worldwide interface oversee, as it offers a plentiful of sources and right now comprises of various sensors.

The fundamental control framework in home automation makes utilization of a wi-fi Bluetooth device offers wi-fi access to PDAs turned into another approach completed by University Technology Malaysia (UTM) understudy, Ahmed Sirajuddin Ahmed Alhaj. He asserts that framework configuration does never again take away the predominant electrical switches and gives a more secure control over the switches with low voltage utilization strategy. The switches are synchronized ever where everybody interface exhibits the advanced present switch notoriety. This contraption is intended to represent electric devices of the living arrangement viably of introducing it. This structure is planned to help and convey help to fulfill the wants of the elderly and the debilitated at homes. Besides, the idea of home mechanization framework likewise will enhance the normal living status at houses [23].

GSM is a flexible correspondence all through the around the world. The GSM famous transformed into discharged with the guide of ETSI (European Telecommunications Standard Institute) in 1989 to clarify the conventions for the second-period advanced portable system used by cell device [24]. The essential business organizations had been propelled in 1991 and when its underlying introduction transformed into completed in Europe, the standard went worldwide in 1992. Because of the reality, GSM has transformed into the greatest broadly grasped and quickly developing the propelled standard, and it is situated to transform into the world's advanced cell across the region the use of the GSM idea and hypothesis was been utilized as a part of this task. In this way, this prompts a venture to deliver a framework that applied GSM innovation as a strategy for manage the electrical appliances or gadgets in the house. Short messaging system (SMS) is the essential part of the contribution to the project completion. By utilizing all the above procedure, the project intended to work for which it can operate the electrical loads and gadgets in the house.

This paper presents a wireless operation to switch on and off the load such as light, fan and power socket by sending messages via smartphone. The proposed project is focused on usage of the GSM protocol, which enables the user to control loads away from targeted area using the frequency bandwidths.

\section{METHODOLOGY}

This chapter incorporate the progression includes in making the home mechanization framework utilizing GSM, arduino UNO, transfer driver IC, hand-off and liquid crystal display (LCD) show. It likewise examined quickly about stream of the framework working begin from sending message until the point when the move made by arduino uno. Orders, for example, letters in order are utilized for controlling home apparatuses. Figure 1 shows the system block diagram. As in the figure, the mobile device consists of a 
subscriber identity module (SIM) card of a particular number on mobile phone which communication takes place. This gadgets communicates through radio frequency with the GSM modem. Cellular users then transmits SMS for the usage of GSM generation. GSM modem is a hardware component which have capability to permit SMS from acquire/ ship and from/to the gadget. The conversation takes place via shield which is basic serial communication between a microcontroller and a personal computer (PC) or GSM modem.

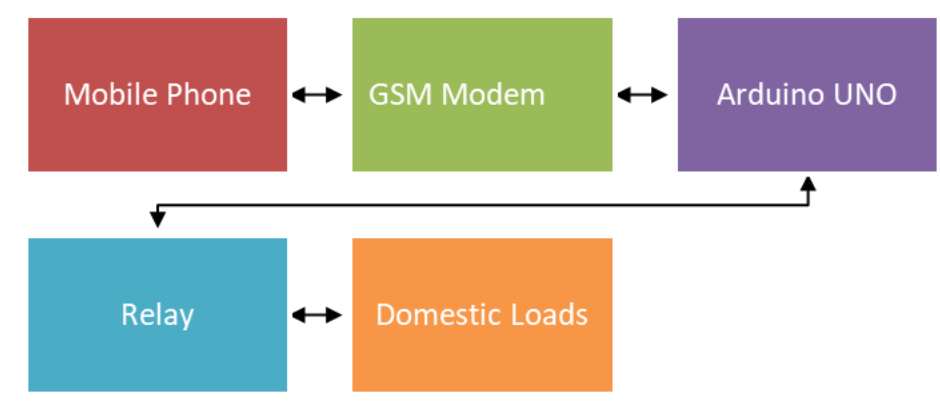

Figure 1. System operation

Arduino UNO is a common Arduino that uses ATmega328 [25]. It has 14 input / output digital pin, an oscillator crystal $16 \mathrm{MHz}$, a power jack, a USB connection, a reset button and an ICSP header [26]. Arduino gets the message through GSM, it sends the flag to transfers to turn on or off the home apparatuses utilizing hand-off driver. At the point when the message is sent from GSM module of mobile to GSM module in arduino, the arduino peruses the message by removing the primary summon from the got message and stores it in a variable. After this, arduino contrasts the summon and predefined order. On the off chance that the order is coordinated then arduino sends flag to transfer through the hand-off driver for turning ON and OFF the home machine and at the same time result is shown on LCD by utilizing fitting charges. Relay interface separate power supply from loads by activating and deactivating process. Relay is an electrical switch that opens and closes under the control of another electrical circuit. The switch is operated by an electromagnet to open or close one or many sets of contacts, in the original form. Because a relay is able to control an output circuit of higher power than the input circuit, it can be considered, in a broad sense, to be a form of an electrical amplifier.

\subsection{Preparation of GSM Module}

Before the system works, several steps are done to ensure the smoothness of operation. First, a SIM card is inserted and locked into the GSM module. GSM is powered up by connecting it to Arduino's 5V and GND port. Antenna is connected to the SMA connector and tighten it via rotating the nut. After a minute, a 'status LED' in the GSM module blink and connection is established successfully once the LED continuously blinking every 3 seconds. The most effective baud rate supported with the aid of the modem is among 9600 and 115200 [27]. The modem routinely sets to the baud rate of the primary command sent through the host gadget after it is powered up. Consumer have to first send "A" to synchronize the baud rate. It is endorsed to wait 2 to 3 seconds earlier than sending "AT" character. After receiving the "ok" reaction, the tool and GSM modem are efficiently synchronized. So there may be no want for putting the baud rate the use of instructions. Make sure the SIM card inserted in module first for support the wanted features and also be credited sufficient balance in SIM.

\subsection{Circuit Schematic}

The schematic diagram for this project consist of the components that were used such as Arduino Uno microcontroller, GSM modem, relay, IC ULN 2003 driver, LCD display, and loads. Figure 2 shows the schematic diagram of the system. It can be seen clearly the connection arrangement of these components into and out from the UNO microcontroller in order to control the turning on and turning off loads. Loads in this purpose are TV, light, and fan. All switches use one relay each. 


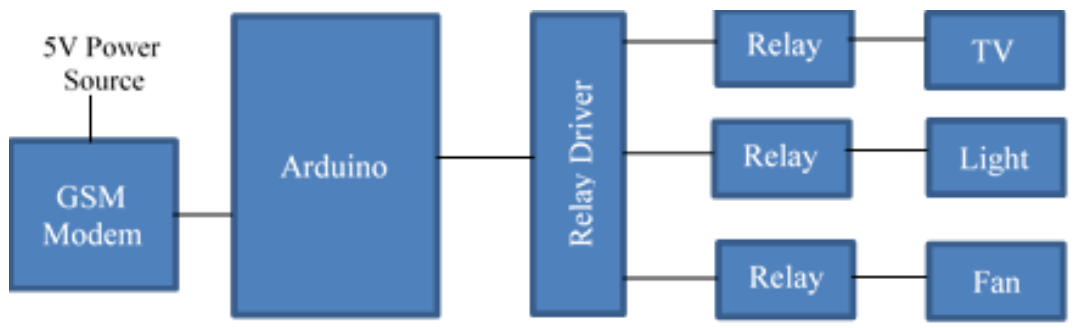

Figure 2. Circuit schematic of proposed system

\section{RESULTS AND ANALYSIS}

The designed prototype intends to demonstrate by sending/receiving the SMS from and to the GSM modem through user mobile to control the home appliances. Standard set of AT commands controlled the GSM modem. For the ubiquitous access of appliances, SMS sending and receiving is used and allowing breach to control at home. The users can control the home appliances system remotely. To change the condition of the home appliances, it is capable to instruct via SMS from a specific cell. Following paragraph discussed on the software program evaluation on how the $\mathrm{C}$ programming operated and function.

First element is GSM modem and microcontroller become initialized. Secondly, the following mode layout, "AT $+\mathrm{CMGF}=1$ " command was accomplished before sending other command. Following via the SMS at reminiscence location 1 inside the sim card of GSM modem turned into deleted and GSM modem turned into prepared to get hold of SMS message from consumer now. As soon as SMS became obtained, the SMS might be study and check the content whether or not it is correct or no longer. The convenient output to switch on or off the appliances only can be despatched if the content material do not have any error.

GSM electronic equipment or movable are coupled to the computer/pc and began out a terminal program (including HyperTerminal on Microsoft windows). Currently first command area unit equipped to travel into the first issue before user input the command is to check the communication among the pc and GSM modem/mobile phone to verify that the complete ton is running properly. To carry out a look, truly enter "AT" command, then it sends lower back the ultimate result code "ok" to indicate that it has received the command with success. Set up the GSM shield always in standby mode which establishing connection between arduino to receive the message. The sending message could not be decoded if the Arduino does not communicated well with GSM. So, GSM failed to get instructions which allow the controller switching the appliances. As an example, when SMS message sent 'a' to the SIM card number on the GSM modem to make relay 1 'on', where the TV is connected, LCD screen will display as 'TV is on'. When SMS message sent ' $b$ ' for relay 1 is 'off', LCD screen will display as 'TV is off'. Table 1 shows all the settings done in the system.

Table 1. Setting for prototype testing

\begin{tabular}{clccc}
\hline Input (SMS) & Output on LCD Display & Output Relay 1 (TV) & Output Relay 2 (Fan) & Output Relay 3 (Light) \\
\hline a & TV IS ON & On & Off & Off \\
b & TV IS OFF & Off & Off & Off \\
c & FAN IS ON & Off & On & Off \\
d & FAN IS OFF & Off & Off & Off \\
e & LIGHT IS ON & Off & Off & On \\
f & LIGHT IS OFF & Off & Off & Off \\
g & ALL LOAD IS ON & On & On & On \\
h & ALL LOAD IS OFF & Off & Off & Off \\
\hline
\end{tabular}

\section{CONCLUSION}

This system is designed to control electrical devices throughout the house with easy installation process, ease of use and cost effective design and implement. Additionally, the system has several possibility to help satisfy the needs of the elderly and the handicapped at houses. Prototype of GSM based domestic electrical load control using arduino uno was implemented and tested successfully.

\section{ACKNOWLEDGEMENTS}

The authors would like to acknowledge Universiti Tun Hussein Onn Malaysia (UTHM), Batu Pahat, Johor, Malaysia for the financial support of this paper under H157 (Tier 1) Grant. 


\section{REFERENCES}

[1] Vini Madan and S.R.N Reddy, "GSM-Bluetooth based Remote Monitoring and Control System with Automatic Light Controller," International Journal of Computer Applications, vol. 46, no. 1, pp. 20-28, May 2012

[2] S. Faroom, M. N. Ali, S. Yousaf and S. U. Deen, "Literature review on home automation system for physically disabled peoples," 2018 International Conference on Computing, Mathematics and Engineering Technologies (iCoMET), Sukkur, 2018, pp. 1-5.

[3] Ahmed ElShafee and Karim Alaa Hamed, "Design and Implementation of a WiFi Based Home Automation System," World Academy of Science, Engineering and Technology, no. 68, pp. 2177-2183, Aug 2012.

[4] Carl J. Debono and Kurt Abela, "Implementation of a Home Automation System through a Central FPGA Controller," 16th Electro-technical Conference (MELECON), IEEE, pp. 641-644, 25-28 Mar. 2012.

[5] U. Ali, S. J. Nawaz and N. Jawad, "A Real-time Control System for Home/Office appliances automation, from mobile device through GPRS network," 2006 13th IEEE International Conference on Electronics, Circuits and Systems, Nice, 2006, pp. 854-857.

[6] Alkar, A.Z., and Buhur, U. "An Internet Based Wireless Home Automation System for Multifunctional Devices," IEEE Consumer electronics, vol. 51(4), pp. 1169-1174, 2012.

[7] Ajah, G, David, N, Abioye, A, "Home automation using Arduino," Sch. J. Eng. Tech, vol. 1(3), pp. 112-116, 2013.

[8] Chennakesavan, C. "Implementation of cloud connected smart plug with energy monitoring system," Indonesian Journal of Electrical Engineering and Computer Science, vol. 8(3), pp. 702-704, 2017.

[9] M. Asadullah and K. Ullah, "Smart home automation system using Bluetooth technology," 2017 International Conference on Innovations in Electrical Engineering and Computational Technologies (ICIEECT), Karachi, 2017, pp. 1-6.

[10] M. Aguado et al., "Towards zero on-site testing: Advanced traffic management \& control systems simulation framework including communication KPIs and response to failure events," 2014 IEEE 6th International Symposium on Wireless Vehicular Communications (WiVeC 2014), Vancouver, BC, 2014, pp. 1-2.

[11] Peng Wang, Lixiang Yan, Jun Wang and Yuancheng Zhu, "The remote intelligent controlling and monitoring system of home appliances based on GPRS/GSM," 2010 IEEE International Conference on Information Theory and Information Security, Beijing, 2010, pp. 958-961.

[12] N. M. Morshed, G. M. Muid-Ur-Rahman, M. R. Karim and H. U. Zaman, "Microcontroller based home automation system using Bluetooth, GSM, Wi-Fi and DTMF," 2015 International Conference on Advances in Electrical Engineering (ICAEE), Dhaka, 2015, pp. 101-104.

[13] P. M. Corcoran, P. Bigioi and E. Steinberg, "Wireless transfer of images from a digital camera to the Internet via a standard GSM mobile phone," IEEE Transactions on Consumer Electronics, vol. 47, no. 3, pp. 542-547, Aug. 2001.

[14] Ooi C.P et al, "FPGA-based embedded architecture for iot home automation application," Indonesian Journal of Electrical Engineering and Computer Science, vol. 14(2), pp. 646-652, 2019.

[15] A. Mulla, J. Baviskar, J. Desai, C. Beral and A. Jadhav, "GSM based interactive voice response system for wireless load control and monitoring," 2015 International Conference on Communication, Information \& Computing Technology (ICCICT), Mumbai, 2015, pp. 1-6.

[16] H. Wang, S. Xu and H. Sui, "An Automatic Supervisory Control System Based on Real-Time Embedded Technology and GSM or GPRS Network," 2008 4th International Conference on Wireless Communications, Networking and Mobile Computing, Dalian, 2008, pp. 1-4.

[17] G.Sridhar and M.Srinivas, "Home Automatic Control System using Bluetooth and Android Mobile", International Journal of Innovative Technologies (IJITECH), Vol. 3(6), 2015, pp 937-940.

[18] K.Shivaram, N.Rajendra, K.Mahesh, and K.B. Murthy, P.Jawahar, "Power line communication based automation system using a handheld Wi-Fi device”, IEEE International Conference on Consumer Electronics. 10, 1-6, 2012.

[19] Ghosh, Shreya \& Konar, Subhasree \& Ghosh, Soumen \& Ghosh, Tanumay \& Gope, Suvojit, "Dual Tone Multiple Frequency Based Home Automation System”, International Journal of Engineering Research, 4(10), pp 542-544, 2015.

[20] F.K.C.Harun, C.M.Onn, N.M.A.M.Basri, "Voice Recognition Home Automation System (VRHAS)", Jurnal Teknologi, 54(Sains\&Kej), Keluaran Khas, Jan 2011, pp 361-369.

[21] T. Ramli, N. N. Dabimel, M. Mamat, N. Parimon, R. R. Porle, "Simple Speech Controlled Home Automation System using Android Devices", Journal of Scientific Research and Development, Vol.3(1),pp 33-38, 2016.

[22] E. Effah, F. L. Aryeh, W. K. Kehinde, "GSM-Based Home Appliances Control System for Domestic Power Users in Ghana," Ghana Journal of Technology, vol.1, no. 1, pp. 25-31, Sep 16, 2016.

[23] Anandan.R, Karthik.B, Kumar.K, "Wireless Home Automation System Using Gsm,” vol. 4, no.4, pp. 126-132, 2013.

[24] Nathan David, Abafor Chima, Aronu Ugochukwu, Edoga Obinna, "Design of a Home Automation System Using Arduino,” International Journal of Scientific \& Engineering Research, vol. 6, no. 6, Jun 2015.

[25] Michael Margolis, “Arduino Cookbook," 2nd ed., Shawn Wallace and Brian Jepson, Eds. California, United States of America: O’Reilly Media, Inc., 2011.

[26] F. Ramon Lara and M. Dolores Redel F. Javier Jimenez, "API for communication between Labview and Arduino UNO,” IEEE Latin America Transactions, vol. 12, no. 6, pp. 971-976, Sep 2014.

[27] Poonam B. Patil, Rupali R. Patil, Swati V.Patil, Avadhoot R.Telepatil, "Home Automation System Using Android and Arduino Board," International Journal of Innovative Research in Science, Engineering and Technology, vol. 5, no. 4, Apr 2016. 


\section{BIOGRAPHIES OF AUTHORS}
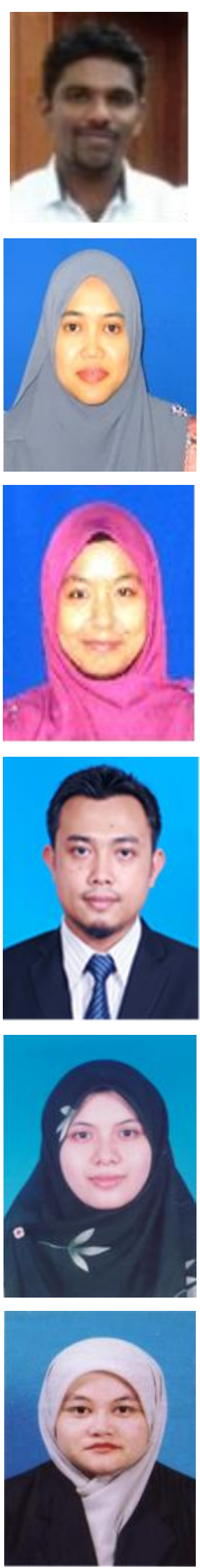

Logeswaran A/L Velusamy studied in Bachelor of Degree in Electrical Engineering at Universiti Tun Hussien Onn Malaysia, Batu Pahat, Johor.. The author's major field of study is electrical engineering

Suriana Salimin is a lecturer in Faculty of Electrical Engineering (FKEE), UTHM. After graduated from her first degree in Eletrical Engineering (UTM-2006), she worked as a tutor in UTHM for 6 months and continued for MSc in Power Distribution Engineering in Newcastle University (2007). She completed her $\mathrm{PhD}$ in Electrical Engineering in 2014 also from Newcastle University, UK. She has published a few papers in Jurnals and proceeding since 2013. Her research interests are on power quality improvement, distributed generation systems, renewable energy and harmonics mitigation.

Siti Nurfatihah Mohamad Rozi currently studying Bachelor of Degree in Electrical Engineering at Universiti Tun Hussien Onn Malaysia, Batu Pahat, Johor, 2019. The author's major field of study is electrical engineering.

Mohd Noor Abdullah received his B.Eng. (Hons) in Electrical Engineering and M. Eng. in Electrical Engineering (Power System) from Universiti Teknologi Malaysia (UTM) in 2008 and 2010 respectively. He also received a Ph.D degree in Electrical Engineering from University of Malaya (UM) in 2014. He has been with Universiti Tun Hussein Onn Malaysia (UTHM) from 2008 to 2014 as a tutor. He is currently as a Lecturer in Department of Electrical Power Engineering, Faculty of Electrical and Electronic Engineering (FKEE), Universiti Tun Hussein Onn Malaysia (UTHM). He also appointed as a head of Green and Sustainable Energy (GSEnergy) Focus Group in FKEE, UTHM. He was a member of Board of Engineer Malaysia and IEEE. His research interests include electric power dispatch, distributed generation, renewable energy and meta-heuristic optimization techniques.

Nur Hanis Muhammad Radzi received her B.Eng. and M.Eng in Electrical Engineering (Power) from Universiti Teknologi Malaysia (UTM) in 2005 and 2009 respectively, and Ph.D from The University of Queensland, Brisbane, Australia in 2012. Currently, she is a senior lecturer in the Faculty of Electrical \& Electronic Engineering at Universiti Tun Hussein Onn Malaysia (UTHM). Her research interests include transmission pricing, power system economics, energy management and renewable energy.

Siti Amely Jumaat was born in Johor, Malaysia on March 12, 1979. She graduated from the Institut Tun Hussein Onn (ITTHO-UTM) with honours degree in BSc. Electrical Eng. in 2001, MEng. (Power), UTM in 2003, and PhD in Electrical Eng at UiTM, Malaysia in 2015. Her research interests include power system and optimization techniques, FACTS devices, Artificial Intelligent techniques and renewable energy system. She is also a member of BEM, IEM, IEEE, and IEEE Power Engineering Society (PES) 2008. 


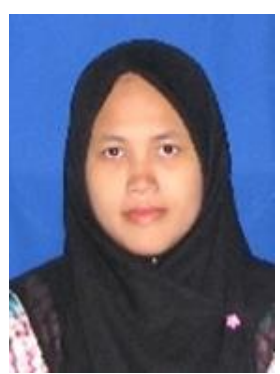

Rohaiza Hamdan is a lecturer in Department of Electrical Power Engineering, Faculty of Electrical and Electronic Engineering (FKEE), UTHM since 2003. She got her first degree in Electrical Power Engineering from Universiti Tenaga Nasional (UNITEN) on 2003. Three years later, she is granted with MSc. Electrical Power Engineering from Universiti Teknologi Malaysia, UTM. Her research interest evolved between power system stability, renewable energy and advance control applications. 